\title{
Evaluation of health literacy and drug use attitudes and behaviors of patients admitting to dermatology clinic
}

\section{Dermatoloji polikliniğgine başvuran hastaların sağlık okur-yazarlığı ile ilaç kullanım tutum ve davranışlarının değerlendirilmesi}

Rukiye Yasak Güiner ${ }^{1}$, Mustafa Tosun¹, Melih Akyol ${ }^{1}$,Sibel Berksoy Hayta ${ }^{2}$, Saliha Özpınar ${ }^{3}$

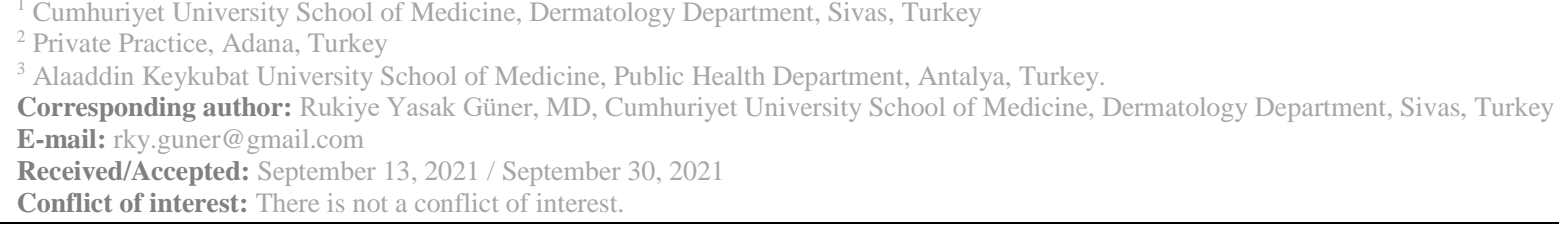

\section{SUMMARY}

Objective: In the present study, the purpose was to investigate the relationship between health literacy levels and drug use attitudes and behaviors of patients admitting to dermatology outpatient clinics.

Method: A total of 295 volunteers admitting to Sivas Cumhuriyet University Dermatology Clinic between 1/03/2020 and 31/12/2020 were included in the study. Two forms were used to collect the data in the study. These were the Data Collection Form and the Health Literacy Scale.

Results: The mean age of the participants was $33.0 \pm 16.36$; and $62.0 \%$ of them were women. The mean score of the participants in Health Literacy Scale was $4.60 \pm 0.2$; and it can be argued that the health literacy levels of the participants were high. The relations between health literacy and dermatological drug use attitudes and behaviors were evaluated with the Correlation Analysis; and a significant relation was detected between the two variables $(\mathrm{p}<0.05)$.

Conclusions: Dermatology patients have high health literacy and their dermatological drug use attitudes and behaviors are at adequate levels.

Keywords: Health literacy, rational drug use, dermatology
(D) Rukiye Yasak Güner
(D) Mustafa Tosun
(iD) Melih Akyol
(D) Sibel Berksoy Hayta
(D) Saliha Özpınar

ORCID IDs of the authors: R.Y.G. 0000-0002-5154-4652 M.T. 0000-0002-6189-8016 M.A. 0000-0001-7912-0651 S.B.H. 0000-0002-6185-6094 S.Ö. 0000-0002-9860-996X

\section{ÖZET}

Amaç: Bu çalışmada dermatoloji polikliniğine başvuran hastaların sağlık okuryazarlığı düzeyleri ile ilaç kullanım tutum ve davranışları arasındaki ilişkinin araştırılması amaçlanmıştır.

Yöntem: Çalışmaya toplam 295 gönüllü dahil edildi. Araştırmada verilerin toplanmasında Veri Toplama Formu ve Sağlık Okuryazarlığı Ölçeği kullanılmıștır. Verilerin değerlendirilmesinde yapılan normallik testine göre veriler normal dağılıma uymadığından farklı testler için Mann Whitney U-Testi ve Kruskal Wallis Testi kullanılmış; değişkenler arasındaki ilişkileri değerlendirmek için Spearman Korelasyon Analizi kullanılmıştır.

Bulgular: Katılımcıların Sağlık Okuryazarlı̆̆ düzeylerinin yüksek olduğu söylenebilir. Sağlık okuryazarlığı ile dermatolojik ilaç kullanım tutum ve davranışları arasındaki ilişkiler Korelasyon Analizi ile değerlendirilmiş; ve iki değişken arasında anlamlı bir ilişki saptandı ( $\mathrm{p}<0.05$ ). Sonuç: Dermatoloji hastalarının sağlık okuryazarlığı yüksektir ve dermatolojik ilaç kullanım tutum ve davranışları yeterli düzeydedir.

Anahtar sözcükler: Sağl1k okuryazarlığı, ilaç kullanımı, dermatoloji 


\section{INTRODUCTION}

World Health Organization defines health literacy as "the ability of individuals to access, understand and use their health knowledge for the protection and maintenance of health". Low health literacy levels cause difficulties in understanding healthrelated information and messages, high level of illness in individuals, less use of preventive healthcare services, problems in accessing healthcare services, greater use of emergency services, increased incidence in chronic diseases and hospitalizations ${ }^{1}$.

Every member of society should have adequate healthcare knowledge to make decisions about health, not only the ability to read and understand. Health literacy, beyond reading-writing skills, covers healthy behaviors, the ability to understand and evaluate healthcare information such as correct use of medications, knowing how to benefit from healthcare services, understanding and signing informed consent forms, making decisions on selfcare and disease management, and using medical devices at home correctly ${ }^{2}$.

Inadequate health literacy can cause unhealthy life, lack of knowledge on chronic diseases, difficulty in understanding the education provided, lack of knowledge on health and preventive healthcare services (e.g. screening, vaccines, exercise) and problems in using these services, difficulty in complying with the treatment provided (i.e. medication, control, etc.), increase in the rate of hospitalization and increase in healthcare expenses 3.

Rational Drug Use (RDU) is defined as being able to provide the appropriate drug at the lowest price and easily, at the appropriate time and dose according to the clinical findings and individual characteristics ${ }^{4}$.

Non-rational drug use continues to pose a serious problem that affects public healthcare. Because of non-rational drug use, there may be increases in diseases and mortality rates, in the risk of side effects of drugs, and decreases in accessibility to even basic medicines because of improper consumption of the country's resources, resistance develop to drugs, and the need for new treatment options appears ${ }^{5}$.

Non-realistic drug use behaviors include improper drug use, multiple drug use, unnecessary use of expensive drugs, over-prescription of medications, or using antibiotics unnecessarily ${ }^{6}$. Rational drug use is a process starting with rational selection of drugs, and responsible stakeholders of the process include doctors who prescribe drugs, pharmacists providing drug logistics, healthcare employees who administer the drug, and patients using the drug. Right at this point, it is considered that it is important to measure the knowledge and behavior levels of the stakeholders to achieve rational drug use policies at desired levels in healthcare systems 7,8 .

The purpose of the present study was to investigate the relations between health literacy levels and drug use attitudes and behaviors of patients admitting to the dermatology clinic.

\section{MATERIAL AND METHODS}

The purpose of the study, which was designed in a cross-sectional fashion, was to determine the relations between health literacy and rational drug use in the sampling of dermatology patients.

Throughout the study, all the individuals admitting to the dermatology clinic, who were over the age of 18 , and who agreed to participate in the study, were included in the study. The study data were collected between 1/03/2020 and 31/12/2020. Being volunteers was essential in the study, the patient had the right to terminate the study at any time s/he wished. Two forms were used to collect the data in the present study. These were the data Collection Form and the Health Literacy Scale.

Data Collection Form: The Data Collection Form consisted of two parts. In the first part, sociodemographic characteristics, such as age, gender, education and income levels were questioned. The health-disease status of individuals, drug use characteristics, information status regarding drug use, and dermatological drug use attitudes and behaviors were questioned in the second part. The score of " 2 " was given to each correct behavior, "1" to those who responded as "sometimes", and " 0 " to each incorrect behavior, and the total score was obtained in this way to obtain the drug use attitude and behavior score.

Health Literacy Scale (TR): The 47-item HLSE.U (Health Literacy Survey in Europe), which was developed by Sorensen, was used in this study. The form was then simplified by Tochi, Bruzari and Sorenson working together, and its Turkish validity and reliability study was conducted by Aras and Baylk. The scale consisted of 25 items and four sub-dimensions. It was found that the health literacy scale had a high level Cronbach's Alpha internal reliability coefficient ${ }^{9,10}$.

Statistical Analysis: According to the normality test done in the evaluation of the data (Shapiro 
Wilk), since the data did not match normal distribution, the Mann Whitney U-test and Kruskal Wallis Test were used for difference tests; and Spearman Correlation Analysis was used in the relations between variables. Also, basic-level descriptive statistics, such as frequency, percentage, and median were used in the analysis of the socio-demographic and economic data. In the study, which was conducted within a 95\% Confidence Interval, the significance level of the $\boldsymbol{p}$ value was taken as $p<0.05$. The IBM SPSS V.22 Program was used to analyze the data.

\section{RESULTS}

When the socio-demographic characteristics and descriptive information of a total of 295 participants were examined, it was found that $62.0 \%$ of the participants were women, $63.8 \%$ were under the age of $31,57.6 \%$ were single, $56.9 \%$ were high school graduates, and $32.9 \%$ were students. It was determined that $72.3 \%$ of the participants did not have any chronic diseases, $68.8 \%$ did not have continuously used medication, $51.1 \%$ sometimes read books/newspapers/ magazines, $65.0 \%$ had moderate income level perception, and $42.0 \%$ had good overall health status perception.

When Table 1 is examined, it is seen that 83.1 of the participants said that they first admitted to their doctors in case of a dermatological complaint; $13.5 \%$ of them did not use the drug prescribed for their dermatological problems. When asked why, $32.5 \%$ of them said that they did not use it because they did not benefit from the drug. The drug form, which $52.5 \%$ of the participants did not use for dermatological problems, was found to be pomade/ointment/lotion.

Table 1: Drug use characteristics

\begin{tabular}{|c|c|c|c|}
\hline Statements & & $\mathrm{n}$ & $\%$ \\
\hline \multirow{4}{*}{$\begin{array}{l}\text { The first procedure performed in the presence of a } \\
\text { dermatological complaint }\end{array}$} & Using the drug already present at home & 36 & 12,2 \\
\hline & Taking drugs from neighbours / friends & 4 & 1,4 \\
\hline & Buying drugs from a pharmacy & 10 & 3,3 \\
\hline & Seeing a physician & 245 & 83,1 \\
\hline \multirow{2}{*}{$\begin{array}{l}\text { Drug status prescribed for your dermatological } \\
\text { problems but you do not use }\end{array}$} & Yes & 40 & 13,5 \\
\hline & No & 255 & 86,5 \\
\hline \multirow{7}{*}{$\begin{array}{l}\text { The reason for not using drugs prescribed for your } \\
\text { dermatological problems }\end{array}$} & Bad taste & 3 & 7,5 \\
\hline & I don't want the treatment & 4 & 10 \\
\hline & I did not get any benefit & 13 & 32,5 \\
\hline & I forget to take the drug & 4 & 10 \\
\hline & It is expensive, I can not afford it & 1 & 2,5 \\
\hline & I don't care about it & 5 & 12,5 \\
\hline & Others & 10 & 25,0 \\
\hline \multirow{3}{*}{$\begin{array}{l}\text { The drug form prescribed for your dermatological } \\
\text { problems but you do not use }\end{array}$} & Pomade / cream / lotion & 21 & 52,5 \\
\hline & Tablet / capsule / dragee & 17 & 42,5 \\
\hline & Suspension / syrup / sachet & 2 & 5,0 \\
\hline
\end{tabular}

The information status of the participants on their drug use for dermatological treatment is examined in Table 2. In this respect, $87.1 \%$ of the participants said that they knew the purpose of drugs, and $48.1 \%$ knew some of their side effects. A total of $41.3 \%$ of the respondents reported that they stored drugs in a closet; and $89.1 \%$ said that they received information about the drugs they used, $81.3 \%$ said that doctors were the source of information. A total of $97.2 \%$ of the participants said that they understood the information they received, and $87.4 \%$ found this information sufficient; $13.5 \%$ said that they had trouble in reaching healthcare institutions, and $70.8 \%$ said that they had a relative who could help with drug use. 
Table 2: Information on drug use in dermatological treatment

\begin{tabular}{|l|l|l|l|}
\hline Statements & & $\mathrm{n}$ & $\%$ \\
\hline Knowing the purpose of using drugs & Yes & 257 & 87,1 \\
\cline { 2 - 4 } & No & 38 & 12,9 \\
\hline \multirow{4}{*}{ Knowing the side effects of the drugs } & I know all the side effects of drugs & 106 & 35,9 \\
\cline { 2 - 4 } & I know some of the side effects of drugs & 142 & 48,1 \\
\cline { 2 - 4 } & I do not know the side effects of drugs & 47 & 16,0 \\
\hline \multirow{4}{*}{ Storing drugs } & Refrigerator & 64 & 21,6 \\
\cline { 2 - 4 } & Cabin & 122 & 41,3 \\
\cline { 2 - 4 } & Somewhere outside (table, small table.....) & 97 & 32,8 \\
\cline { 2 - 4 } & Others & 12 & 4,3 \\
\hline \multirow{4}{*}{ Getting information about the drugs you use } & Yes & 263 & 89,1 \\
\cline { 2 - 4 } & No & 32 & 10,9 \\
\hline The person you got the information & Physician & 240 & 81,3 \\
\cline { 2 - 4 } & Nurse & 12 & 4,0 \\
\cline { 2 - 4 } & Pharmacist & 33 & 11,2 \\
\cline { 2 - 4 } & Others & 10 & 3,5 \\
\hline \multirow{4}{*}{$\begin{array}{l}\text { Understanding the information you receive } \\
\text { drug use }\end{array}$} & Yes & 287 & 97,2 \\
\cline { 2 - 4 } received sufficient & No & 9 & 2,8 \\
\hline \multirow{2}{*}{$\begin{array}{l}\text { Problems in reaching the health institution } \\
\text { The }\end{array}$} & Yes & 258 & 87,4 \\
\cline { 2 - 4 } & No & 37 & 12,6 \\
\cline { 2 - 4 } & Yes & 40 & 13,5 \\
\cline { 2 - 4 } & No & 255 & 86,5 \\
\cline { 2 - 4 } & Yes & 209 & 70,8 \\
\cline { 2 - 4 } & No & 29,2 \\
\hline
\end{tabular}

When Table 3, which provides descriptive statistics of the scales, is examined, it is seen that the Health Literacy Scale has a median of $4.60 \pm 0.2$. It can be argued that the median of dermatological drug use attitudes and behaviors of the participants was high at $1.56 \pm 0.36$. The sub-dimension of the health literacy scale that has the highest median is $4.80 \pm 1.00$ in access to information, and application/use sub-dimension at $4.80 \pm 0.80$, and the lowest is appraisal/evaluation sub-dimension with $4.50 \pm 1.125$.

Table 3: Descriptive statistics of dermatological drug use attitudes and behaviors in health literacy scale

\begin{tabular}{|l|c|c|c|c|}
\hline & $\mathrm{n}$ & median & $\mathrm{IQR}( \pm)$ & Min.- Max. \\
\hline Health literacy & 295 & 4,60 & 0,92 & $1-5$ \\
\hline Access to information & 295 & 4,80 & 1,00 & $1-5$ \\
\hline Understanding the information & 295 & 4,57 & 1,00 & $1-5$ \\
\hline Appraisal / evaluation & 295 & 4,50 & 1,125 & $1-5$ \\
\hline Application / usage & 295 & 4,80 & 0,80 & $1-5$ \\
\hline Attitudes and behaviors of using dermatological drug & 295 & 1,56 & 0,36 & $0-2$ \\
\hline
\end{tabular}


When Table 4 is examined, it is seen that significant differences were detected in the health literacy levels of the participants in favor of those who were under 31 years of age, single, at least university graduate, who had a chronic disease, and those without continuous drug use $(\mathrm{p}<0.05)$. Significant differences were also detected between the health literacy levels of participants and their overall health status perceptions, income levels, and frequency of reading books/newspapers/journals $(\mathrm{p}<0.05)$. It was found that this significant difference in terms of income levels was between those with low and good income levels, and between those with moderate and good income levels, in favor of those who had good income levels. In terms of Overall Health Status Perception, significant differences were detected between "none and moderate", "moderate and good", "moderate and very good" and "good and very good" groups $(\mathrm{p}<0.05)$. In terms of the frequency of reading books/newspapers/journals, significant differences were detected between "none and sometimes", "none and often", and "sometimes and often", in favor of "frequently" $(\mathrm{p}<0.05)$.

Table 4: Comparison of health literacy scale and sociodemographic characteristics

\begin{tabular}{|c|c|c|c|}
\hline \multirow[t]{2}{*}{ Variables } & \multirow[t]{2}{*}{ Qualifications } & \multicolumn{2}{|c|}{ Health Literacy Scale } \\
\hline & & median \pm IQR & $p$ \\
\hline \multirow[t]{2}{*}{ Sex } & Female & $4,64 \pm 1,02$ & \multirow[t]{2}{*}{0,399} \\
\hline & Male & $4,52 \pm 0,74$ & \\
\hline \multirow[t]{2}{*}{ Age } & $\leq 30$ & $4,76 \pm 0,64$ & \multirow[t]{2}{*}{0,000} \\
\hline & $\geq 31$ & $4,34 \pm 1,14$ & \\
\hline \multirow[t]{2}{*}{ Marital status } & Single & $4,80 \pm 0,64$ & \multirow[t]{2}{*}{0,000} \\
\hline & Married & $4,36 \pm 1,04$ & \\
\hline \multirow[t]{2}{*}{ Education level } & $\leq$ High School & $4,36 \pm 1,16$ & \multirow[t]{2}{*}{0,000} \\
\hline & $>$ High School & $4,80 \pm 0,68$ & \\
\hline Income level & \begin{tabular}{|l|} 
Good \\
Medium \\
Low
\end{tabular} & $\begin{array}{l}4,88 \pm 0,64 \\
4,52 \pm 1,07 \\
4,42 \pm 0,76\end{array}$ & 0,003 \\
\hline Occupation & \begin{tabular}{|l} 
Housewife \\
Retired \\
Student \\
Public employee \\
Private sector employee \\
Tradesman \\
Unemployed
\end{tabular} & $\begin{array}{l}4,60 \pm 0,96 \\
4,86 \pm 0,91 \\
3,60 \pm 0,67 \\
4,76 \pm 0,78 \\
4,40 \pm 0,98 \\
4,48 \pm 1,20 \\
3,84 \pm 1,95\end{array}$ & 0,068 \\
\hline $\begin{array}{l}\text { Frequency of reading book / newspaper / } \\
\text { magazine }\end{array}$ & $\begin{array}{l}\text { Never } \\
\text { Occasionally } \\
\text { Frequently }\end{array}$ & $\begin{array}{l}3,72 \pm 1,35 \\
4,60 \pm 0,79 \\
4,80 \pm 0,61\end{array}$ & 0,000 \\
\hline Status of chronic diseases & $\begin{array}{l}\text { Yes } \\
\text { No }\end{array}$ & $\begin{array}{l}4,44 \pm 1,43 \\
4,64 \pm 0,80\end{array}$ & 0,03 \\
\hline Drug used continuously & \begin{tabular}{|l|} 
Yes \\
No \\
\end{tabular} & $\begin{array}{l}4,52 \pm 1,08 \\
4,64 \pm 0,72 \\
\end{array}$ & 0,014 \\
\hline General health condition perception & $\begin{array}{l}\text { Very good } \\
\text { Good } \\
\text { Medium } \\
\text { Low } \\
\text { None }\end{array}$ & $\begin{array}{c}4,86 \pm 0,48 \\
4,58 \pm 0,81 \\
4,40 \pm 1,13 \\
4,42 \pm 0,85 \\
4,80 \pm 1,16\end{array}$ & 0,000 \\
\hline
\end{tabular}


When the attitudes and behaviors of the participants are examined in Table 5, the statements the participants agreed at the highest rate were; the recommendation of taking the drugs hungry or full with $92.2 \%$, using the drugs at the recommended dose with $90.5 \%$, and paid attention to the expiration date with $86.1 \%$. The highest rate of participants who did not agree was; requesting antibiotics with prescriptions with $77.8 \%$, requesting digestive system medication on prescription with $77.7 \%$, and using medication based on the advice of others with $71.6 \%$.

Table 5: Dermatological drug use attitudes and behaviors

\begin{tabular}{|c|c|c|c|c|c|c|}
\hline Variables & $\begin{array}{l}\text { Yes } \\
\text { n }\end{array}$ & $\%$ & $\begin{array}{l}\text { Occa } \\
\text { n }\end{array}$ & $\%$ & $\begin{array}{l}\text { No } \\
\text { n }\end{array}$ & $\%$ \\
\hline Taking drug on time & 239 & $\% 81,0$ & 8 & $(\% 2,7)$ & 48 & $(\% 16,3)$ \\
\hline $\begin{array}{l}\text { Using the drug as often as } \\
\text { recommended }\end{array}$ & 260 & $\% 88,1$ & 0 & $(\% 0)$ & 35 & $(\% 11,9)$ \\
\hline $\begin{array}{l}\text { Using the drug at the } \\
\text { recommended dosage }\end{array}$ & 267 & $\% 90,5)$ & 25 & $(\% 8,4)$ & 3 & $(\% 1,1)$ \\
\hline $\begin{array}{l}\text { Paying attention to the } \\
\text { expiration date }\end{array}$ & 254 & $\% 86,1)$ & 26 & $(\% 8,8)$ & 15 & $(\% 5,1)$ \\
\hline $\begin{array}{l}\text { Following the } \\
\text { recommendation to get } \\
\text { the drug hungry or full }\end{array}$ & 272 & $\% 92,2)$ & 18 & $(\%$ 6,1) & 5 & $(\% 1,7)$ \\
\hline $\begin{array}{l}\text { Recommending the drug } \\
\text { to others }\end{array}$ & 55 & $\% 18,6)$ & 69 & $(\% 23,3)$ & 171 & $(\% 58,1)$ \\
\hline $\begin{array}{l}\text { Giving ther drug to the } \\
\text { others }\end{array}$ & 28 & $\% 9,4)$ & 72 & $(\% 24,4)$ & 195 & $(\% 66,2)$ \\
\hline $\begin{array}{l}\text { Taking drugs upon } \\
\text { advice of others }\end{array}$ & 26 & $\% 8,8)$ & 58 & $(\% 19,6)$ & 211 & $(\% 71,6)$ \\
\hline $\begin{array}{l}\text { Taking drugs from the } \\
\text { others }\end{array}$ & 27 & $\% 9,1)$ & 61 & $(\% 20,6)$ & 207 & $(\% 70,3)$ \\
\hline $\begin{array}{l}\text { Buying over-the-counter } \\
\text { drugs at the pharmacy }\end{array}$ & 45 & $\% 15,2)$ & 98 & $(\% 33,2)$ & 152 & $(\% 51,6)$ \\
\hline $\begin{array}{l}\text { Asking for pain relief on } \\
\text { prescription }\end{array}$ & 57 & $\% 19,3)$ & 84 & $(\% 28,4)$ & 154 & $(\% 52,3)$ \\
\hline $\begin{array}{l}\text { Asking for antibiotics on } \\
\text { prescription }\end{array}$ & 25 & $(\% 8,4)$ & 41 & $(\% 13,8)$ & 229 & $(\% 77,8)$ \\
\hline $\begin{array}{l}\text { Asking for digestive } \\
\text { system drug on } \\
\text { prescription }\end{array}$ & 29 & $(\% 9,8)$ & 37 & $(\% 12,5)$ & 229 & $(\% 77,7)$ \\
\hline $\begin{array}{l}\text { Checking the expiration } \\
\text { dates of drugs }\end{array}$ & 220 & $(\% 74,5)$ & 49 & $(\% 16,6)$ & 26 & $(\% 8,9)$ \\
\hline Reading the prospectus & 203 & $(\%$ 68,8) & 52 & $(\% 17,6)$ & 40 & $(\% 13,6)$ \\
\hline
\end{tabular}

According to the results of the Correlation Analysis,a statistically significant and very weak relation was detected between health literacy and dermatological drug use attitudes and behaviors $(\mathrm{p}<0.05)$.

It was found in the present study that the health literacy scale and subgroups of the scale had significant and high-level relations $(\mathrm{p}<0.05)$. A positive relation was detected between access to information and understanding information dimensions with a coefficient of .587 , a positive relation was detected between access to information and the evaluation sub-dimension at .662 , a positive relation was also detected between access to information and application subdimension with the coefficient of .539 , and a positive relation was detected with health literacy with the coefficient of .778 . A positive relation was detected between the sub-dimension of understanding information and evaluation with the coefficient of .690 , and a positive relation was detected between the understanding of information and the application sub-dimension with a coefficient of .603. A positive relation was detected 
between understanding the information and the total score of health literacy with the coefficient of .851. A positive relation was detected between the evaluation and application sub-dimensions with a coefficient of .677. A positive relation was detected at .788 between the application sub-dimension and the total score of health literacy.

\section{DISCUSSION}

It is known that poor health literacy is associated with inadequate compliance to drug use, increased hospitalization and mortality ${ }^{11}$. In this context, it can be speculated that determining and improving the health literacy levels of patients is important for effective disease management.

Non-rational drug use is a major problem on a global scale. The World Health Organization estimates that more than half of all the drugs are prescribed, distributed, or sold improperly, and approximately half of all patients do not receive drugs correctly. Rational Drug Use, which was developed as an important approach to fight against this problem, covers drug use in the doses that cover the clinical needs of patients, their individual requirements at sufficient time with the lowest cost for themselves and their societies ${ }^{12}$. In our study, it can be argued that the dermatological drug use attitudes and behaviors of the participants were high, along with the health literacy levels of the participants according to the Health Literacy Scale. It can also be argued that the participants had high levels of access to information, understanding, appraisal/evaluation and application/use of information in the sub-dimensions of health literacy. Unlike our findings, health literacy of patients was found to be low in the some studies ${ }^{13-}$ 16. In another study conducted with university students by Özpinar et al., it was found that the knowledge levels on skin cancer prevention methods were inadequate ${ }^{17}$. Significant differences were detected in the health literacy levels of the participants in favor of those who were under 31 years of age, single, at least university graduate, who had a chronic disease, and those without medications used continuously. In the study conducted by Gücük et al., it was found that age, marital status, and education affected health literacy ${ }^{18}$. Previous studies reported that health literacy was effective in the early detection and prevention of chronic diseases ${ }^{19}$.

Although no significant differences were detected between gender and health literacy in the present study, in the study of Cho et al. it was found that there were lower health literacy scores in women ${ }^{20}$.Significant differences were detected between the health literacy levels of the participants and their overall health status perception, income levels, and frequency of reading books/news papers/journals.

When the knowledge and attitudes towards rational drug use of the participants were evaluated, many participants said that when they had a dermatological complaint, they first contacted their doctor, and used the prescribed drugs. One-third of those who do not use the recommended drugs said that they did not use them because they did not benefit from them. Many of the participants said that they received information about the drugs from their doctors, understood the information they received, and found this information sufficient.

When dermatological drug use attitudes and behaviors of the participants were evaluated, it was found that many participants agreed on the statements regarding issues such as taking drugs on time, using drugs at recommended interval and dose, paying attention to the expiry date, and complying with the recommendations on taking drugs when hungry or full. The relations between health literacy and dermatological drug use attitudes and behaviors were evaluated with the correlation analysis; and significant relations were detected between the two variables, and these relations were very weak.

It is necessary to minimize the risks for drugs in rational drug use, achieve effectiveness, compliance, safety and cost analysis of drugs, ensure accurate information and patient participation. Legal measures, access to accurate information, and education are the leading tools to promote rational drug use. Although certain progress was covered in the world in this respect and in Turkey, the problems in the use of drugs still continue. Formal and informal educational opportunities are used and developed to increase awareness in rational drug use. Necessary administrative arrangements must also be carried out to protect and support the attitudes and behaviors acquired in addition to education. Drug policies must be shaped in this regard. In this way, it is possible to achieve the expected benefits from drugs ${ }^{21}$.

Health literacy encourages individuals to better understand their health conditions, participate in the treatment process actively in the management of chronic diseases, benefit from preventive healthcare services, and take more responsibility for their health ${ }^{22}$.

\section{CONCLUSION}

Since many dermatological diseases have chronic progression, disease management and patient 
adaptation to treatment are important for the effectiveness of the treatment. Right at this point, the importance of health literacy and rational drug use comes to the forefront. In the present study, it can be argued that dermatology patients have high health literacy levels, and generally show rational drug use attitudes and behaviors.

\section{Acknowledgements}

This research did not receive any specific funding.

\section{Ethics approval}

Approval was obtained from the ethics committee of Cumhuriyet University Medical Faculty Hospital Clinical Trials ( Decision number: 2020$02 / 12$ ). The procedures used in this study adhere to the tenets of the Declaration of Helsinki and in our study, consent forms were obtained from individuals in order to use information about patients

\section{Conflicts of interest}

The authors declare no conflicts of interest.

\section{REFERENCES}

1. Avcı E, Özkan S. Dünyada ve Türkiye'de sağlık okuryazarlığı düzeyi ve etkileyen faktörler. Özkan S, editör. Sağlık Okuryazarlığı. 1. Baskı. Ankara: Türkiye Klinikleri; 2019; 16-21.

2. Yilmaz M, Tiraki Z. What is Health Literacy? How to Measure? Dokuz Eylul University Faculty of Nursing Electronic Journal. 2016;9 (4):142-147.

3. Parker RM, Baker DW, Williams MV, Nurss JR. The test of functional health literacy in adults. . J Gen Intern Med. 1995;10(10): 537-541.

4. World Health Organization .Conference of Experts on the Rational Use of Drugs; 1985. Available at https apps who int iris handle 10665 623112529.12.

5. Neden Akılcı İlaç Kullanımı? Avaible at http://www.akilciilac.gov.tr/?page_id=81.

6. Ilhan M, Aydemir O, Cakır M, Aycan S. A study in three districts of Ankara of behaviors associated with irrational use of drugs. Pharmacoepidemiol. 2009;18(12):1150-1157.

7. Ekenler S, Kocoglu D. Individuals' Knowledge and Practices About Rational Drug Use. Hacettepe University Nursing Faculty Journal. 2016;3 (3), 4445.

8. Tosun, N., Tosun, M., \& Gökalp, Y. (2018). Determination of Rational Drug Use Situations of Patients Attending to The Secondary Health Care Institution. The Journal of Social Sciences, 5(27), 370-385 .
9. Aras Z, Temel Bayik A. Evaluation of the Validity and Reliability of the Turkish Form of the Health Literacy Scale. Florence Nightingale Nursing Journal.2017; 25(2), 85-84.

10. Toci E, Burazeri G, Sorensen K, Naser NJ, Roshi RE, Brand H. Health literacy and socioeconomic characteristics among older people in transitional Kosovo.Journal of Advances in Medicine and Medical Research, 2013;3(4):16461658.

11. Berkman ND, Sheridan S L, Donahue KE. Halpern DJ, Karen Crottyet K. Low health literacy and health outcomes: an updated systematic review. Annals of internal medicine.2011; 155(2): 97-107.

12. World Health Organization. The pursuit of responsible use of medicines: sharing and learning fromcountryexperiences.2012.Avaibleathttps://w ww.who.int/medicines/publications/responsible_u se/en/

13. Ergun S. Health Literacy in Health High School Students. Kocaeli Medical Journal.2017; 6 (3): 1-6.

14. Yakar B, Gomleksiz M, Pirincci E.Health literacy levels of patients admitted to a university hospital outpatient clinic and influencing factors. Euras J Fam Med.2019; 8(1), 27-25.

15. Bakan A.B, Yıldız M.A Study on Determining the Health Literacy Levels of Individuals Aged 2164. Health and Society.2019; 29(3): 33-30.

16. Koc A, Tayaz E, Uysal, N , Oztas D. The most important component of the service use side in health care: health literacy. Ankara Medical Journal.2020; 20 (1); 205-213.

17. Ozpınar S, Celik Odabası N, Akyol M. Associations between health literacy and preventive Skin Cancer Prevention Strategies among University Students. Journal of Health Literacy.2020;5(3): 12-25.

18. Gucuk S, Dilekc1 E ,Kayhan M. Health Literacy of Patients Hospitalized with Musculoskeletal System Complaints and Utilization of Primary Health Care Services. Eurasian Journal Of Family Medicine.2020;9(3):131-138.

19. Taggart J, Williams A, Dennis S, Newall A, Shortus T, Zwar $\mathrm{N}$ et al. A systematic review of interventions in primary care to improve health literacy for chronic disease behavioral risk factors. BMC family practice.2012; 13(1): 1-12.

20. Cho YI, Lee SYD, Arozullah AM, Crittendenet KS et al. Effects of health literacy on 
health status and health service utilization amongst the elderly. Social science \& medicine.2008; 66(8):1809-1816.

21. Aydın B, Gelal A. Rational drug use: its dissemination and the role of medical education.
Dokuz Eylul University Faculty of Medicine Journal.2012;26(1):57-53

22. Nielsen-Bohlman L, Panzer AM, Kindig DA .Health Literacy: A Prescription to End Confusion, National Academies Press, Washington, 2004;3135. 